\title{
MOBILE APPS AS A TOOL FOR DESTINATION MANAGEMENT - CASE STUDY OF BELGRADE
}

\author{
Snežana Štetić1 \\ Dario Šimičević ${ }^{2}$ \\ Jelena Aksentijević3 ${ }^{3}$ \\ Igor Trišić ${ }^{4}$
}

DOI: https://doi.org/10.31410/tmt.2020.569

\begin{abstract}
Mobile applications, as a very dynamic segment of modern ICT (Information and Communication Technology), are in widespread use in tourism. Tourist destinations are increasingly using mobile applications to manage the development of a destination product, that is, the applications themselves are seen as an important part of the destination product and the overall tourists' experience. This paper focuses on mobile applications and their use in destination management and the achievement of overall tourist satisfaction. Special attention is paid to the use of mobile applications in the management of tourism development in Belgrade as well as the impact of mobile applications on tourists' experience of Belgrade as a tourist destination.
\end{abstract}

Keywords: Information and communication technology, Tourists' satisfaction, Smart destination.

\section{INTRODUCTION}

$\mathrm{T}$ oday, more than ever, the modern tourism market is constantly adapting to the new information and communication technologies (ICTs) that have led to a series of changes in the tourism market, which are manifested both on the tourist supply side and the tourist demand side (Štetić \& Šimičević, 2014). ICTs have become a source of competitive advantage for the tourism industry and tourist destinations (Buhalis, 1998; Zelenka, 2009) and an indispensable tool in developing a destination product, in creating a tourism offer for individual tourism companies, and in communicating with consumers. Thus, the ignorance of ICTs and avoidance of their implementation in all aspects of business creates negative impacts and increased the competitive advantage of competition (Čavlek et al., 2010). It could be said that the biggest changes and benefits are for both, tourist demand and tourism economy, in the field of ICTs, which gives new opportunities and tools to the tourism managers, but also the consumers themselves (Štetić \& Šimičević, 2014). Neuhofer also assigns a new role to information and communication technology as a mediator in going through a new experience and/or as the basis of a new experience around which it is created (Štetić et al., 2017).

The dominance of ICTs in the tourism business is in line with trends in the tourism market. These trends are reflected in consumer's behaviour changes, i.e. tourists, which directly affect the business of different companies and entrepreneurs (Van Wee et al., 2013), including companies and organizations in tourism. The main trends in tourism companies and organizations influenced by modern ICT are (Gu et al., 2016; Ammirato et al., 2014):

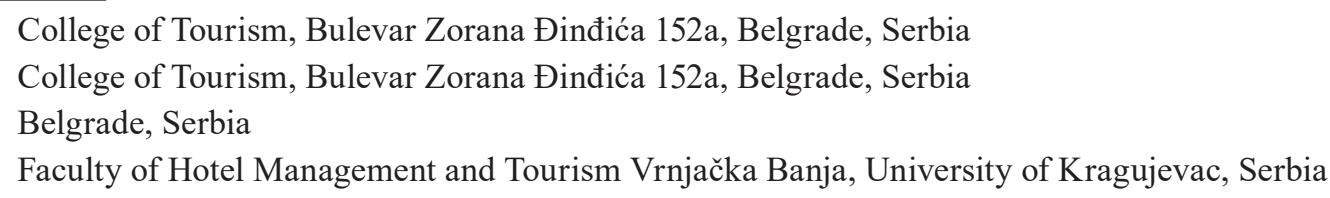


1. Big data analysis with lower overall costs in time and money,

2. Interactive contact with consumers and increase in the share of direct sales,

3. Overall reduction of costs, shortening of timeframes for the provision of services and operations increased quality of work and efficiency.

Also, the development of megacities as tourism destinations, but also as significant outbound centers as well as the increasing demand for ,smart tourism” products (Gu et al., 2016) can be highlighted as important trends. An increasing population of megacities wants to spend their free time within different, better quality surroundings than those in which they live and work, in order to have psycho-physical regeneration and rest. Due to an increasing amount of available information, in their search for such surroundings, they rely on modern information and communication solutions to find services that suit them as efficiently as possible. On the other hand, tourism destinations and businesses use the same information and communication solutions to reach the end consumers as directly and as quickly as possible (Milićević et al., 2020) and to provide them with the information they need quickly and efficiently (Štetić et al., 2019; Trišić et al., 2020). Also, modern technology has enabled the creation of smart tourism products that leads to the establishment of ,smart destinations" that will be fully available to modern tourists (Buhalis \& Law, 2008; Neuhofer et al., 2012; Buhalis \& Amaranggana, 2015, Yalçınkaya et al., 2018).

Smart tourism includes smart tourism experiences that enable tourists to communicate and interact more closely with residents, local businesses, local government, and tourist attractions in cities (Yalçınkaya et al., 2018). Besides, through mutual communication smart tourism should ensure the creation of added value for all stakeholders such as Destination Management Organizations (DMOs), travel agents, tour operators, local communities, tourists (Trišić, 2019), local, regional and national authorities, cultural organizations, heritage sites (Trišić, 2019), transportation organizations and other businesses, institutions, and intermediaries (Koo et al., 2019).

Basically, ,smart tourism” can be observed as the last stage in the development of tourism and tourism destinations (Gretzel et al., 2015; Trišić et al., 2018), and it is based on the application of „top” ICTs and technological systems (Gretzel et al., 2015; Khan et al., 2017). The terms „smart tourism” and „smart destinations” are derived from „smart cities” based on the Internet of Things (IoT), cloud computing, mobile communication, and artificial technology systems (Put-van den Beemt \& Smith, 2016). „Smart city” is not a mono-component but it is a system consisting of „smart elements” as (Khan et al., 2017; Sziva, 2017):

- „smart economy”

- „smart people”

- „smart management”

- „smart mobility”

- „smart environment”

- „smart housing”

Essentially, the use of modern ICTs should ensure the sustainable development of cities integrating all elements of the system into a functional whole. It can be done by maximizing the linkage of human resources to high-tech solutions that will reduce the consumption of material, environmental and social resources, maximizing effects on the population and economy at the same time.

In order to create a ,smart destination”, DMOs need to apply modern ICTs to fulfill their function of creating a destination product, together with its presentation, lobbying for it within the 
economy and with tourists as well as launching it at target markets. To fully implement ICTs in the DMO business we apply Destination Management Systems (DMSs) (Buhalis \& Wagner, 2013) that consist of a network of hardware, software, and software solutions or applications and communication channels, databases, or multiple databases that are available to users through database management systems. Such a DMS fulfills the needs of all participants in a destination, connects and provides information, and stimulates internal and external communication, and supports strategic management decisions. (Martins, et al., 2013). However, it should be noted that the accelerated development of new technologies is not only a chance but also a challenge, and often a problem in managing destinations. Gretzel (2015) identified several fields in which the development of modern ICTs can present a challenge in the effective management of tourism destinations by DMOs. Those are:

1. DMOs websites have ceased to be a dominant source of destination information, and as the alternative sources of information, there are blogs, vlogs, web magazines and newspapers, apps and social media,

2. Most DMOs do not have internal human resources that can keep up with all the changes in modern ICTs, so they are forced to engage external entities to avoid technological backwardness, the irrelevance of communication channels, and poor attendance of online presentations, which can lead to significant costs,

3. With the development of social media and free posting and sharing the content by users, DMOs have lost control over the online marketing contents,

4. Mobile device development requires DMOs to adapt their websites to the requirements of modern „smart devices"

5. DMOs are forced to develop mobile applications as a ubiquitous communication channel and a tool for managing users' movement within a destination,

6. The emergence of portable technology, mini-portable cameras, and drones have set the task to DMOs to connect users with attractions in a destination.

What is particularly interesting and important for „smart tourism” and the development of „smart destinations" is the use of ,smart devices" by tourists, the tourism industry, and DMOs in their daily activities and businesses. Interaction among stakeholders is basic in the smart destination setting and it is articulated through a technological infrastructure composed of smart technologies and solutions. In the smart destination, the DMO takes a pro-active role together with businesses and applies the public-owned smart solutions for engaging tourists at a superior level (Femenia-Serra \& Neuhofer, 2018). One of the segments of applying ICTs and smart devices to achieve smart tourism experiences is to implement mobile applications by tourists before, during, and after the trip and by the tourism industry and DMOs in communication with the market and creation of the tourism product.

\section{LITERATURE REVIEW}

The development of technology in the $21^{\text {st }}$ century has enabled us to be constantly connected with other users, service providers, organizations, and businesses. This development has eventually meant the creation of mobile or portable devices (laptops, tablets, and mobile phones) that people can use anywhere around via wireless Internet connection wherever there is an Internet signal. The combination of smart portable devices and advanced software solutions results in „smart" phones and other „smart" devices that have the functionality and speed of standard PCs. In this way, it is possible to perform a series of more or less complex operations according to the user's needs. Smartphones and other smart devices are recording an unstoppable upward 
growth trend in the mobile market and today over $50 \%$ of all mobile users in the world own smart devices (Kim et al., 2017). This is particularly evident in the markets of the USA and Europe (Tjostheim \& Holmqvist, 2010) where this percentage is even higher.

In order to better understand the importance of mobile applications for modern tourism, it is necessary to define mobile applications and how they work. In this sense:

Jieun sees mobile applications as a software solution that provides information and supports users in their daily or business activities by technical characteristics of the mobile devices on which they are used. On the other hand, Alin has simplified this definition even more and says that mobile applications are a set of coded instructions designed to solve certain problems. (Filofteia, 2016)

Dickinson et al., (2012) say that mobile applications are specifically designed software for mobile devices that improves the delivery of mobile services.

Based on the above-mentioned definitions, it can be concluded that mobile applications are specially developed software solutions that should make users' search for information easier, as well as their order, booking, or payment for certain products and/or services: they facilitate communication with other users or organizations, find entertainment, etc. Thus, mobile applications serve to address the daily needs of users in all areas of their lives and save time and money in the process of solving these problems. All applications could be classified into 7 basic groups (Schieder, 2013; Kiilunen, 2013):

1. navigation applications use GPS, augmented reality, and other location services to show users their location and route to the desired point (most commonly used as navigation applications for travel, but also to navigate within destinations);

2. social networking applications allow users to share content and to communicate with other users; in addition to social networking applications, it is possible to instantly share content between these and other tourist applications by linking them through software solutions, and such solutions can also be introduced into destination applications;

3. mobile marketing applications provide information on discounts, rewards, competitions, etc.;

4. travel safety applications provide information on various safety aspects during travel, from medical warnings to natural disasters and safety of certain parts of the destination from crime, etc.;

5. transaction applications include a whole set of applications for purchasing, bookings, banking and other financial services, auctions, etc.;

6. information applications offer a wide range of services from translation and currency calculations to destination information, itinerary creation, event calendars, etc.;

7. entertainment applications such as various games, TV, music, photo editing, and their sharing, eBooks, or applications for downloading and displaying books, etc.

Mobile applications are developed by individuals or organizations and they can be targeted at specialized users or the wider public. Important is that they are simple, understandable, and easy to use. The most popular services for mobile application downloading are the Google Play Store and the Apple App Store, with several million different downloadable applications.

The development of the mobile application market leads to the development of applications for tourism needs, i.e., the applications which are intended for tourists in all three stages of travel, 
before, during, and after the trip itself. The increasing use of mobile applications is also matched with the widespread use of mobile devices by tourists. A survey conducted by DCS + Travel Technologies found that a large proportion of common and business travellers use mobile devices at all stages of the tourism cycle, as can be seen in Table 1.

Table 1. The percentage of mobile device usage by tourists during the stages of the tourist cycle (\%)

\begin{tabular}{|l|c|c|c|c|}
\cline { 2 - 5 } \multicolumn{1}{c|}{} & \multicolumn{2}{c|}{ Common tourists } & \multicolumn{2}{c|}{ Business travellers } \\
\cline { 2 - 5 } \multicolumn{1}{c|}{} & Desktop/tablet & Mobile phone & Desktop/tablet & Mobile phone \\
\hline Total at any stage & 94 & 67 & 97 & 78 \\
\hline Imagination / Inspiration & 73 & 31 & 74 & 39 \\
\hline Research & 88 & 27 & 86 & 36 \\
\hline Booking / Purchase & 81 & 14 & 84 & 28 \\
\hline Travel / Experience & 57 & 50 & 67 & 54 \\
\hline Sharing / After the trip & 63 & 37 & 67 & 42 \\
\hline
\end{tabular}

Source: http://www.dcsplus.net/hubfs/PDF/Resources/How-mobile-apps-are-changing-travel-habits. pdf?t=1531405451357

The disadvantage of the research presented in Table 1 is that tablets, which by their nature are mobile devices, are placed in the same category as desktop devices. If they were to be classified as mobile phones, certainly, the percentage of mobile devices used at all stages of the tourism cycle would be much higher. However, it can be concluded that the percentage of mobile usage increases significantly during the travel and sharing stage, i.e. in the last stage of the cycle, when tourism applications are significantly used to share content and comments on certain services.

\section{STATE-OF-THE-PLAY AND NEW TRENDS IN USING MOBILE APPS IN TOURISM}

Mobile applications for tourism purposes can be categorized into a smaller or larger number of groups or categories, some authors list even 12 categories of tourism applications. (Dickinson et al., 2012). Smirnov et al., (2014) grouped all applications into applications that collect information relevant to tourists through Internet sources, i.e. those that require an Internet connection in order to show tourists relevant information locally and temporally and applications that have their databases and do not require an Internet connection to show information relevant to tourists. Regardless of the number of categories, it should be emphasized that today tourism applications make extensive use of modern technology achievements. They incorporate the capabilities of mobile devices to use GPS, proximity sensors, gyroscopes, and other technical solutions (Dickinson et al., 2012; Kim \& Kim, 2017) allowing applications to make the most of technical components of the devices. Thus, they make it easier for tourists to obtain the information they want. Therefore, the focus of tourism mobile applications are tourists and/or groups of tourists (Da Silva \& Rocha, 2012). We can say that there is a large number of tourist applications dealing with all aspects of the organization and realization of tourist travel and with all aspects of one tourist destination, from the provision of basic services to online reservations and payment services in the destination. Their role, number, and types will only grow over time.

Still, mobile application implementations through digital travel guides, digital maps, and ratings of tourism services remain the most common. In this regard, integrated GPS devices are widely used to a great extent by all ,smart" phones and tablets and timely marked information is available on the Internet (Tjostheim \& Holmqvist, 2010). Thus, users are provided with spatially 
and temporally relevant information based on where they stay and the time at which the desired information is requested. Mobile or digital guides are a commonly used type of application by tourists and these applications provide situationally dependent multimedia services for visitors while recommending attractions that are close to the visitor or related to the activities he prefers. This type of application is the best indicator of incorporating GPS and time information. (Smirnov et al., 2014; Kourouthanassis et al., 2014) By providing location-based services, digital travel guides can provide time - and location-relevant information to tourists based on their location. Thus, through digital maps or other means of presenting information, they inform tourists about sales networks, traffic, accommodation facilities, restaurants, etc., which is the best way to inform tourists about activities in the destination.

It may be easiest to illustrate the importance and impact of mobile applications in tourism through the applications for tourism service rating. These applications can be used at the moment of consuming a service or after travelling. For tourists, this is not a new option as they were already able to rate their trip through the services introduced by TripAdvisor in the early $21^{\text {st }}$ century. What is new is that this option is now widely implemented within tourism applications and thanks to the use of „smart" mobile devices, tourists can rate the quality of services and facilities instantly, on the go. They can also share it with a wider community that uses the same application, thus creating an e-WOM (electronic word-of-mouth) that has an instant effect on the behaviour of other users. Furthermore, this affects their use or non-use of certain tourist services (Kim \& Kim, 2017).

Also, increasing implementation of AR (Augmented Reality) within tourism applications can be expected in the coming period (Nabeen et al., 2016). AR enables full integration of the simulated environment with the real one implementing 2D and 3D objects into applications. (Ajanki et al., 2011; Kounavis et al., 2012; Kečkeš \& Tomičić, 2017) One example of AR implementation in tourism applications is „Here WeGo" where 3D objects of the most important and most interesting tourist locations are inserted into the drivers' navigation maps of a particular destination. The aim is to make it easier for tourists to reach it and to draw attention to potentially attractive sights in the city. Importantly, AR content within applications can be presented in a variety of formats, from the text, through photos and drawings to video. The greatest use of AR today is within digital tourist guides, digital maps (of a city, transport, etc.), archeological sites and areas where historical events significant for a particular destination took place, etc. In any case, modern tourists respond positively to the use of AR, and smartphones have finally enabled tourists to use AR massively through integration with mobile applications (Kečkeš \& Tomičić, 2017).

Nowadays, mobile applications play an important role in destination management as a part of a broader corpus of modern ICTs. DMOs are challenged to plan and implement technological solutions, which benefit both the own destination from a public perspective and the tourists visiting it (Femenia-Serra \& Neuhofer, 2018). DMOs are using mobile apps in order to provide tourists with information, but also to direct tourists' movements in the destination as well as to promote certain parts of the destination product. DMOs can create general-purpose mobile applications for the general public with the most important destination information, such as accommodation facilities, attractions, restaurants and bars, cycling and other trails, parking locations, retail network, destination history, digital destination maps, etc. They can also launch applications targeted at particular segments where they act as guides through cultural events, informing tourists on festivals, shopping, adrenaline sports, and destination opportunities in this regard, etc. Currently, there are several general-purpose destination applications on the 
market that provide information on all aspects of the destination. Their weakness is that these pieces of information are mostly summarized and tourists interested in specific aspects of a destination, for example in its cultural offer, can find out only some of the most general information or a list of cultural institutions in these applications. Fortunately, the software solutions available today make it possible to connect these applications to cultural institutions' sites, digital maps, and virtual guides through museums, minimizing this weakness and making it almost invisible to users.

In the process of creating destination applications, DMOs should focus on tourists' needs and provide answers to four basic tourists' questions during their stay in the destination. These questions are: what, how, when, and where, which means that the application should help tourists decide what to see, how to get to a particular attraction or location, to get real-time information to coordinate activities better, and to get to know the area where they move. (Tjostheim \& Holmqvist, 2010). In order for users of destination applications to become loyal and continuously use them, the DMO should design applications in such a manner that they become an alternative source of cognitive satisfaction instead of the mere content that a particular application contains (Yus, 2014).

When it comes to mobile apps, it should be noted that DMOs need to be aware that they are not the only ones that create destination apps. Today, practically all participants on the tourist offer side have their applications. This can be both, the advantage and disadvantage of a tourist destination. The advantage is that more applications are available related to the tourist destination, which increases the visibility of the destination in the tourist market. The disadvantage is that a DMO does not control how tourist offer will present the destination, what information it will provide, and whether it will be in line with destination marketing efforts. Therefore, close cooperation with all destination providers is required in order to send a unique message to the market through various applications. It is also important to avoid tourists being misled and misinterpreting the marketing efforts of a particular DMO. Applications created by business entities in the destination can be classified into (Schieder, 2013):

1. Applications of transport companies such as car rental agencies, airlines, railway; through these applications, tourists can get informed about the services which these companies offer, make booking and payment, as well as get information about the destinations where they operate or have their terminals;

2. Applications of e-tour operators through which they can book trips or individual travel elements and pay for them, but also they can get informed about the destination, its accommodation facilities, attractiveness, etc.; through these applications, one can also interact with other users through users' comments and ratings; the most famous applications of this type are Expedia, Travelocity, etc.;

3. Amusement park applications enhance tourists' experience in the destination itself allowing them to view amusement park activities, book and buy tickets, plan activities within it, and virtual queueing through mobile devices in order to shorten waiting time for some attractions in the park;

4. Accommodation applications of hotels and hotel chains, but also applications that connect owners of private facilities, villas, smaller family-run hotels like Airbnb with tourists; by launching their applications, hotels, and hotel chains are affecting greater market visibility, thus increasing the number of direct promotions and revenues and making their brand recognizable; these applications also provide basic information about the destination in which their accommodation is located, such as the closest attractions, city transport lines, etc. 
Mobile applications as software solutions aimed at specific issues and situations have experienced a real boom in tourism. On their smart mobile devices, tourists have at least one mobile app designed to help them feel comfortable in a tourist destination or get to know it better. It can be said that creating mobile applications in order to manage destinations and tourist experiences is a must, not a choice of DMOs. Modern tourists communicate with other users and their surroundings through applications in their daily lives, and so they require the same during their travels.

\section{RESEARCH AND METHODOLOGY}

The research is aimed at identifying destination mobile applications that the Tourism Organization of Belgrade (TOB), a DMO engaged in developing Belgrade as a tourism destination, promotes on its official website with the links through which these applications can be downloaded to smart devices.

In addition to identifying the mobile apps that TOB recommends to tourists as a useful tool for feeling comfortable in Belgrade, they will also have access to the description of apps, their functions, built-in options, the number of app downloads on Google Play Store as the most used and the largest mobile app store, as well as user ratings at these stores.

In the second part of the research, the obtained results will be compared to the competing destinations near Belgrade, i.e. Zagreb and Budapest as the direct competitors of Belgrade. Thus, it will be seen whether Belgrade as a tourism destination uses the capabilities of mobile applications as a management tool to develop the destination in the right way and following market demands.

\section{CHARACTERISTICS OF THE DESTINATION MOBILE APPS AVAILABLE TO TOURISTS IN BELGRADE}

When the use of tourism mobile applications as a management tool has been explored by TOB, the primary source of information was TOB's official web site, where two tourist applications were recommended to visitors, the „Belgrade Info Guide” and „Belgrade Talking” (http: // www.tob.rs/useful-informations/mobile-app/belgrade-info-guide).

„Belgrade Info Guide” was designed in collaboration with TOB and it has been downloaded to smart devices over 10,000 times with an average user rating of 4.0. It is a digital tourist guide through Belgrade and it consists of several sections or services. It is a multilingual application that can be used in Serbian, English, Russian and Greek and it was last updated in November 2019. The layout of the application is shown in Figure 1. The application contains an offline digital map with over 1500 drawn facilities, from major tourist attractions to accommodation facilities of various types, restaurants, cafes, shopping malls, cinemas, museums, and other facilities of interest to visitors, which should facilitate making decisions on the time spent in Belgrade according to users' personal preferences and wishes, etc. All of these objects can also be accessed through the „Where to ..., , category. The good side of offline digital maps is that users can use them without having to connect to the Internet.

Besides, the application also includes:

- Information on Belgrade through different periods of history, up to these days;

- Calendar of events in Belgrade, covering events of a different character, sporting events, cultural events, etc.; 
- 42 most important sights of Belgrade which, in addition to the textual part, contain multilingual audio explanations and photographs; users can rate or comment on each of the sights, but they can also mark whether they have visited it or not;

- The app also has an „auto mode" function that allows the app to notify users when they are near an attraction and to tell them the most important details about that attraction;

- There is also the section called "My Belgrade" which contains all the locations that the user has saved and which he can later share, comment and rate.

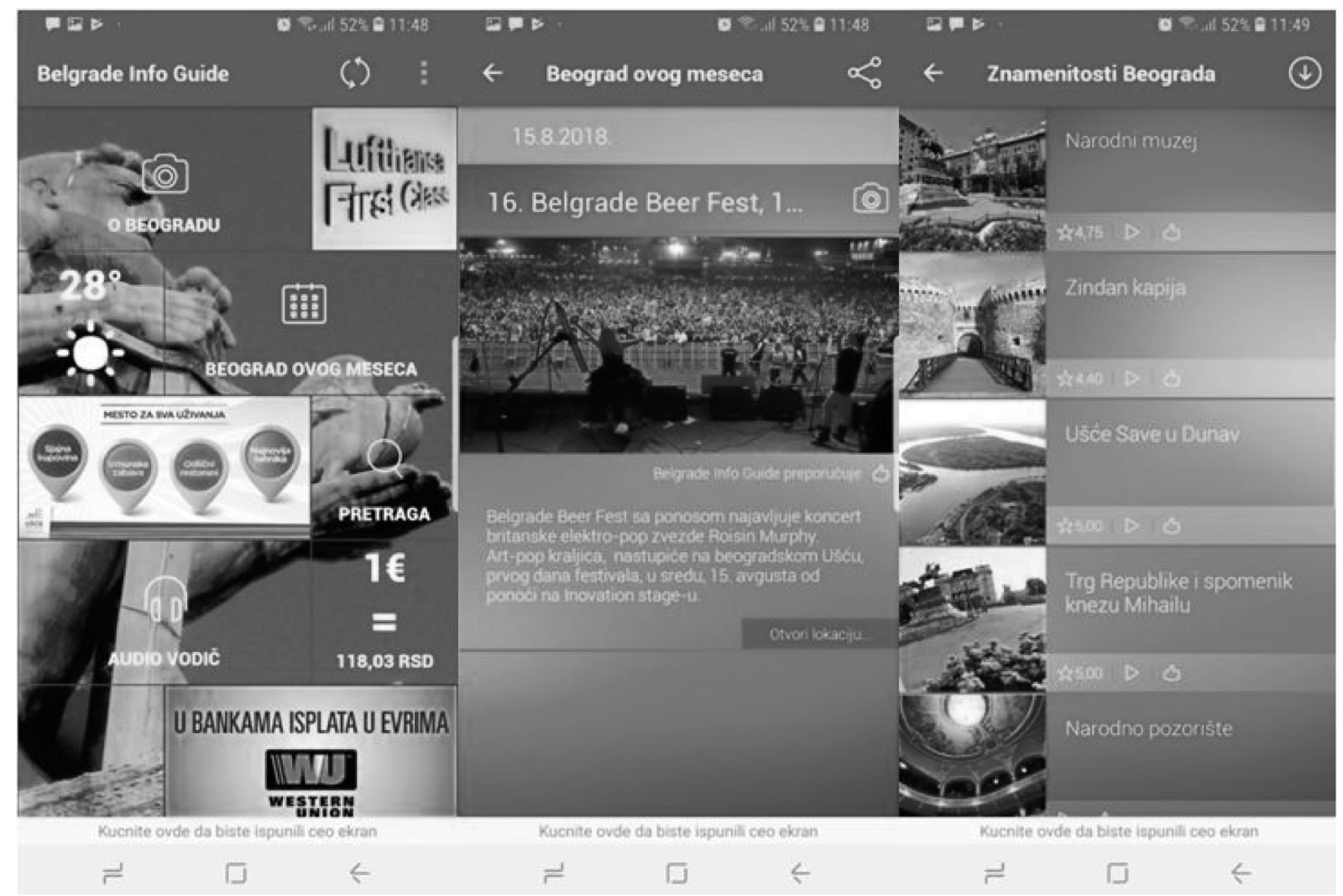

Figure 1. „Belgrade Info Guide” user interface

Source: Screenshots of „Belgrade Info Guide” app

Given that this application is among the leading tourist applications according to the number of downloads, it could be concluded that it is interesting and useful for tourists. More about the application, its features, and ratings can be seen in Table 2 .

Another application presented on TOB's official website is „Belgrade Talking”. Unfortunately, „Belgrade Talking” is no longer available on the Google Play Store and cannot be downloaded on smart devices. This mobile application allowed tourists to find out historical and interesting facts about some of Belgrade's most important locations, buildings, and facilities. The application also contained AR aimed at viewing the environment via mobile phone to obtain information about the facilities located in the user's environment and it offered two functions, „locations” and „walks”. „Locations” were individual places or attractions that the user was able to choose and then to read or hear facts and curiosities about them in audio format. „Walks” were a set of itineraries withdrawn objects on a digital map. Since it can no longer be downloaded, the information about it should be removed from TOB's official website so that users are not misled. 
Table 2. „Belgrade Info Guide” app characteristics, features, and users’ ratings

\begin{tabular}{|c|c|c|c|}
\hline Type of the app & $\begin{array}{l}\text { Number of downloads } \\
\text { on Google Play Store }\end{array}$ & Main features of the app & $\begin{array}{l}\text { Average rate/number } \\
\text { of users' ratings }\end{array}$ \\
\hline $\begin{array}{l}\text { - } \begin{array}{l}\text { Digital tourist } \\
\text { guide }\end{array} \\
\text { guld }\end{array}$ & - $10.000+$ times & $\begin{array}{l}\text { - } \text { Available in } 4 \text { languages } \\
\text { - Offline map with over } 1.500 \text { marked } \\
\text { locations, } \\
\text { - Where to ...?" categories with over } \\
1.000 \text { locations } \\
\text { - Information about Belgrade, its } \\
\text { history, present, and future } \\
\text { - Events calendar } \\
\text { - } 42 \text { Belgrade landmarks with the } \\
\text { multi-language audio guide } \\
\text { - Audio guide with auto mode function } \\
\text { enables the app to notify you that you } \\
\text { are close to some attraction } \\
\text { - My Belgrade" with favourite } \\
\text { locations }\end{array}$ & - 4,0/157 \\
\hline
\end{tabular}

Source: https://play.google.com/store/apps/details?id=rs.bginfobox.belgrade.android\&hl=en

\section{DESTINATION MOBILE APPS IN COMPARISON: BELGRADE VS ZAGREB VS BUDAPEST}

An analysis of Zagreb and Budapest's implementation of mobile applications in managing the development of the two destinations was also carried out in order to get a clearer picture of the position of Belgrade because they represent direct competitors to our town. The sources of information are the official web presentations of DMO Zagreb and Budapest.

An analysis of the official website of the Zagreb Tourist Board, which is Zagreb DMO, revealed that two mobile applications intended for visitors to Zagreb were singled out. The first application is „Zagreb Be There” and the second is „VoiceGuide Zagreb”. „Zagreb Be There” is the Zagreb Tourist Board's destination mobile application and it allows users to get to know Zagreb and some of its less-visited parts, locations, and monuments by choosing routes, locations, and events. Also, visitors can make their lists of favourite sites in the ,wishlist" section. „VoiceGuide Zagreb” app is currently unavailable and cannot be downloaded to smart devices. Otherwise, this application is intended as an audio guide through Zagreb which automatically releases audio information about the attraction when we arrive near it. Besides these two applications, 14 other applications were presented on the official website of Zagreb DMO, which should provide tourists with information about restaurants, purchase of public transportation tickets, taxi services, and ordering rides, etc. These applications are not under the direct control of Zagreb DMO but may be useful to visitors to this destination (https://www.infozagreb.hr/ explore-zagreb/apps).

As regards Budapest, on the official website presentation of the Budapest Festival and Tourism Centre as Budapest DMO there is information on two applications. The first app is the BUM app designed by the Budapest Chamber of Commerce and Industry (BCCI) (https://bevasarloutca. hu/en/about-us). BCCI has made this application in order to revitalize once-famous Budapest shopping streets where economic activity is to be revived. Unfortunately, this application has not been long refreshed and according to information from the Budapest Festival and Tourism Centre website, currently, it does not operate (https://www.budapestinfo.hu/search-results). Another featured application is „Park”, designed to help people find a parking place in Budapest. 
For this research, the applications „Belgrade Info Guide”, „Zagreb Be There” and „BUM”, as official destination applications of Belgrade, Zagreb, and Budapest, were compared on different bases and Table 3 presents the results.

Table 3. Comparison of official destination mobile apps of Belgrade, Zagreb, and Budapest

\begin{tabular}{|c|c|c|c|}
\hline $\begin{array}{l}\text { Features and } \\
\text { characteristics of } \\
\text { selected apps }\end{array}$ & $\begin{array}{l}\text { "Belgrade Info Guide" } \\
\text { app }\end{array}$ & "Zagreb Be There" app & "BUM" app \\
\hline Type of the app & - Digital tourist guide & - Digital tourist guide & - Digital tourist guide \\
\hline $\begin{array}{l}\text { Number of downloads on } \\
\text { Google Play Store }\end{array}$ & - $10.000+$ times & - $10.000+$ times & - $1.000+$ times \\
\hline Main features of the app & $\begin{array}{l}\text { - Available in } 4 \\
\text { languages } \\
\text { - Offline map with } \\
\text { over } 1.500 \text { marked } \\
\text { locations, } \\
\text { - } \text { "Where to ...?" } \\
\text { categories with over } \\
1.000 \text { locations } \\
\text { - Information about } \\
\text { Belgrade, its history, } \\
\text { present, and future } \\
\text { Events calendar } \\
\text { - } 42 \text { Belgrade landmarks } \\
\text { with the multi- } \\
\text { language audio guide } \\
\text { Auto mode function } \\
\text { enables the app to } \\
\text { notify you that you } \\
\text { are close to some } \\
\text { attraction } \\
\text { "My Belgrade" with } \\
\text { favourite locations }\end{array}$ & 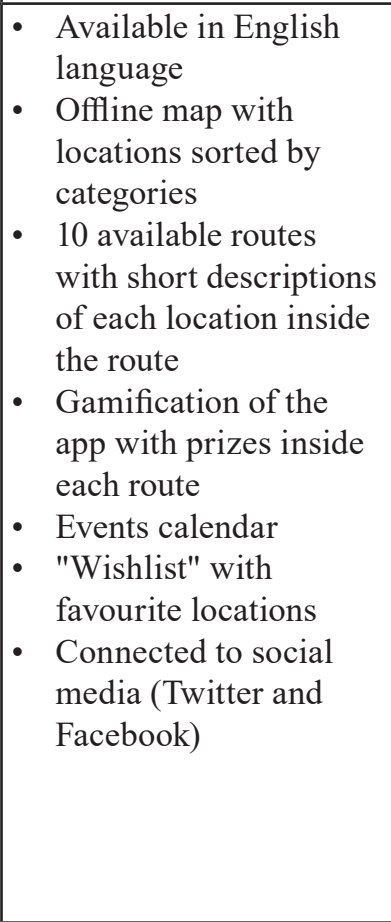 & 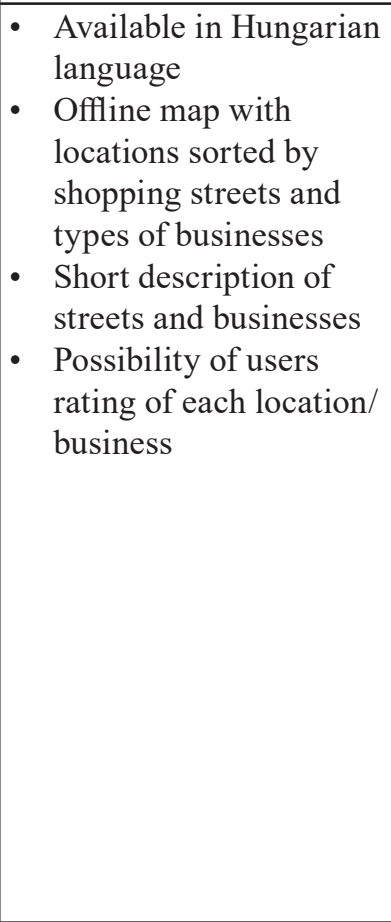 \\
\hline Last app update & - $\quad$ November 2019 & - $\quad$ October 2019 & - $\quad$ October 2017 \\
\hline $\begin{array}{l}\text { Average rate/number of } \\
\text { users' ratings }\end{array}$ & - 4,0/157 & - 3,6/167 & - $2,3 / 7$ \\
\hline
\end{tabular}

Source: https://play.google.com/store/apps/details?id=rs.bginfobox.belgrade.android\&hl=en, https:// play.google.com/store/apps/details?id=co.infinum.zagrebbethere, https:/play.google.com/store/apps/ details?id=hu.bum\&hl=en

All three destinations have one official application, with Zagreb leading by the number of applications for tourists on the Zagreb Tourist Board website. Compared data show that all three applications are from the category of digital tourist guide and that the applications „Belgrade Info Guide” and „Zagreb Be There” have a similar number of downloads with approximately similar users' rating, with a slightly better rating of „Belgrade Info Guide” application. The functions of these two applications are similar and they enable visitors to use offline digital maps, which is important for tourists because they do not have the opportunity to constantly access the Internet. Also, these two applications are regularly updated. „Zagreb Be There” is also gamified because it offers tourists some rewards if they visit most locations within each route. On the other hand, the „BUM” application is not updated regularly, it cannot be downloaded to smart devices at the moment and has a limited number of functions. All this contributed to the dissatisfaction of users who rated this app with only 2.3 out of a possible 5 , proclaiming this to be the worst of the three apps in the observed destinations. 


\section{FUTURE RESEARCH DIRECTIONS}

Prior research on the use of mobile applications conducted by DMOs to develop a destination tourism product and to manage tourists within a destination is important because it shows us how ready destinations are to use modern marketing tools in their day-to-day business. Mobile applications require serious access, regular monitoring of changes in the field, and updating information in the application following the changes. An example of a „BUM” application and poor users' experience due to non-updating data and limited application functions have resulted in extremely low app ratings and low downloads on smart devices.

In the future, it will be interesting to monitor the direction in which mobile applications will develop and whether DMOs will make greater use of the opportunity to integrate modern hardware and software solutions so that they create more comprehensive mobile applications intended for tourists in destinations. It is expected that the functions, interfaces, use of AR, and currently non-existent solutions, which will bring the development of modern ICTs over time, will improve and provide tourists with a completely new experience of tourist destinations. It will also be interesting to monitor the use of mobile applications in the tourist destinations involved in this research, namely in Belgrade, Zagreb, and Budapest.

\section{CONCLUSION}

With the environment digitalization including tourist destinations, and with the appearance of IoT and tourists' switch to mobile smart devices, there have also been tremendous changes in the management of tourist destinations. Mobile applications are now regarded as an indispensable part of the overall tourism offer of a destination and should be viewed in this light. It can be said that tourist mobile applications have their positive and negative sides when it comes to the tourist experience. Positive sides manifest tourists' ability to plan their stay in a destination implementing pre-offered tour itineraries and sharing their impressions, ratings, photos, etc., with other users, approaching the most interesting locations and attractions through text, video, and audio content. By facilitating tourists to feel comfortable within a destination, the use of AR enables tourists to obtain timely and location-relevant information, which positively affects their experience of the destination. Discovering once ,hidden” parts of the destination, tourists will have a new experience that affects overall satisfaction with the destination. The disadvantages of tourist applications are a small number of languages in which they can be used; destinations generally have no control over the content and information provided by applications; they cannot directly affect the accuracy of applications; the number of locations covered by mobile applications is limited; applications need to be constantly updated to avoid their obsolescence; although most applications have offline modes, their full value for tourists is only visible in the online function when it is possible to download information from different databases and to net an application with social networks through the function of sharing content and activities.

Belgrade as a tourist destination has relatively early become aware of the need for developing tourist applications in order to manage the destination and to improve overall tourist experiences during their stay. It is difficult to say to what extent these destination applications affect tourist experiences because the small number of users' reviews with just a few comments is not enough to get a more comprehensive picture. As there is no possibility to contact the users who have downloaded the application, direct analysis of their impact on the destination perception 
cannot be done. This can only be done indirectly through an analysis of rating and the number of downloads. However, comparing Belgrade to Zagreb and Budapest as direct competitors, it can be said that Belgrade, namely TOB, follows current trends in the use of mobile applications as a tool for destination product development. Yet, in many parameters, such as the number and variety of functions, the number of downloads, users' ratings, and updates, TOB is ahead of its observed competitors, especially of Budapest.

\section{REFERENCES}

Ajanki, A., Billinghurst, M., Gamper, H., Järvenpäa”, T., Kandemir, M., Kaski, S., Koskela, M., Kurimo, M., Laaksonen, J., Puolama“ki, K., Ruokolainen, T., \& Tossavainen, T. (2011). An augmented reality interface to contextual information, Virtual Reality, 15(2-3), 161-173. https://doi.org/10.1007/s10055-010-0183-5

Ammirato, S., Della Gala M., \& Felicetti, A.M. (2014). Tourism Destination Management: A Collaborative Approach. In: Camarinha-Matos L.M., Afsarmanesh H. (eds) Collaborative Systems for Smart Networked Environments. PRO-VE 2014. IFIP Advances in Information and Communication Technology, vol. 434. Springer, Berlin, Heidelberg. https://doi. org/10.1007/978-3-662-44745-1_21

Buhalis, D. (1998). Strategic use of information technologies in the tourism industry, Tourism Management, 19(5), 409-421. https://doi.org/10.1016/S0261-5177(98)00038-7

Buhalis, D., \& Amaranggana, A. (2015). Smart Tourism Destinations Enhancing Tourism Experience through Personalisation of Services, in Tussyadiah, I., and Inversini, A., (eds), ENTER 2015 Proceedings, Lugano, Springer-Verlag, Wien, ISBN:9783319143422, 377390.https://doi.org/10.1007/978-3-319-14343-9_28

Buhalis, D., \& Law, R. (2008). Progress in information technology and tourism management: 20 years on and 10 years after the Internet - The state of eTourism research, Tourism Management, 29(4), 609-623. https://doi.org/10.1016/j.tourman.2008.01.005

Buhalis, D., \& Wagner, R. (2013) E-destinations: Global Best Practice in Tourism Technologies and Applications. In: Cantoni L., Xiang Z. (eds) Information and Communication Technologies in Tourism 2013. Springer, Berlin, Heidelberg. https://doi.org/10.1007/978-3-64236309-2 11

Čavlek, N., Matečić, I., \& Ferjanić Hodak, D. (2010). Drivers of innovations in tourism: some theoretical and practical aspects. Acta Turistica, 22(2), 201-220. https://hrcak.srce.hr/70626

Da Silva, A., \& Rocha, H.V. (2012). M-Traveling: Mobile Applications in Tourism. International Journal for Infonomics, 5(3/4). 618-630. https://doi.org/10.20533/iji.1742.4712.2012.0071

Dickinson, J., Ghali, K., Cherrett, T., Speed, C., Davies, N., \& Norgate, S. (2012). Tourism and the Smartphone App: Capabilities, Emerging Practice and Scope in the Travel Domain. Current Issues in Tourism, 17(1). 1-18. https://doi.org/10.1080/13683500.2012.718323

Femenia-Serra, F., \& Neuhofer, B. (2018). Smart tourism experiences: Conceptualisation, key dimensions and research agenda. Investigaciones Regionales, 42. 129-150. https://doi. org/10045/86748

Filofteia, T.M. (2016). Mobile applications for tourism. study regarding their use by Romanians, Annals of the „Constantin Brâncuşi” University of Târgu Jiu, Economy Series, 4, 78-84.

Gretzel, U. (2015). Digital Marketing for Destination Management Organizations, Paper presented at The Bali Tourism Forum International, 1st World Destination Management Outlook. Bali, November 25-27.

Gretzel, U., Sigala, M., Xiang, Z., \& Koo, C. (2015). Smart tourism: foundations and developments. Electronic Markets, 25(3), 179-188. https://doi.org/10.1007/s12525-015-0196-8 
Gu, Z., Zhang, Y., Chen, Y., \& Chang, X. (2016). Analysis of Attraction Features of Tourism Destinations in a Mega-City Based on Check-in Data Mining-A Case Study of Shenzhen, China, International Journal of Geo-Information, 5(11), 210. https://oi.org/10.3390/ ijgi5110210

Kečkeš, A.L., \& Tomičić, I. (2017). Augmented Reality in Tourism - Research and Applications Overview. Interdisciplinary Description of Complex Systems, 15(2), 157-167. https://doi. org/10.7906/indecs.15.2.5

Khan, M., Woo, M., Nam, K., \& Chathoth, P. (2017). Smart city and smart tourism: A case of Dubai. Sustainability, 9(12), 2279. https://doi.org/10.3390/su9122279

Kiilunen, O. (2013). Mobile applications as solutions to enhance sustainable travel behavior among Generation Y, Master's Thesis, HAAGA-HELIA, University of Applied Sciences. Available at https://pdfs.semanticscholar.org/8851/de78ec607a327207b1245d3f01b975b4eble.pdf

Kim, D., \& Kim, S. (2017). The role of mobile technology in tourism: patents, articles, news, and mobile tour app reviews. Sustainability, 9(11), 2082. https://doi.org/10.3390/su9112082

Kim, M., Kim J., Choi J., \& Trivedi M. (2017). Mobile Shopping Through Applications: Understanding Application Possession and Mobile Purchase, Journal of Interactive Marketing 39, 55-68. https://doi.org/10.1016/j.intmar.2017.02.001

Koo, C., Mendes-Filho, L., \& Buhalis, D. (2019). Smart tourism and competitive advantage for stakeholders: Guest editorial. Tourism Review, 74(1), 1-4. https://doi.org/10.1108/TR-022019-208

Kounavis, C.D., Kasimati, A., \& Zamani, E. (2012). Enhancing the Tourism Experience through Mobile Augmented Reality: Challenges and Prospects. International Journal of Engineering Business Management, Special Issue: Digital and Mobile Economy, 4, https://doi. org/10.5772/51644

Kourouthanassis, P., Boletsis, C., Bardaki, C., \& Chasanidou, D. (2014). Tourists responses to mobile augmented reality travel guides: The role of emotions on adoption behaviour, Pervasive and Mobile Computing, 18. 71-87. https://doi.org/10.1016/j.pmcj.2014.08.009

Martins, C., Costa, C., \& Pacheco, O.R. (2013). E-Business strategies for destination management organisations. In Santos, J., Serra, F., Águas, P. (Eds.) TMS Conference Series. Faro. 47- 56. https://doi.org/10198/10828

Milićević, S., Petrović, J., Kostić, M., \& Lakićević, M. (2020). Tourism product in the function of improving destination competitiveness: Case of Vrnjačka Banja, Serbia. Quality - Access to Success, 21(178),133-138.

Nabben, A., Wetzel, E., Oldani, E., Huyeng, J., van de Boel, M., \& Fan, Z. (2016). Smart Technologies in Tourism: Case study on the influence of iBeacons on customer experience during the 2015 SAIL Amsterdam event, Paper presented at International Tourism Student Conference, Madrid, April 19-22, 2016. Available at https://opendataincubator.eu/wp-content/uploads/2016/06/Smart-Technologies-in-Tourism.pdf

Neuhofer, B., Buhalis, D., \& Ladkin, A. (2012). Conceptualising Technology Enhanced Destination Experiences. Journal of Destination Marketing \& Management, 1(1-2). 36-46. https://doi.org/10.1016/j.jdmm.2012.08.001

Put-van den Beemt W.W.S., \& Smith R. (2016). Smart tourism tools: Linking technology to the touristic resources of a city, Paper presented at I Smart Tourism Congress Barcelona, Barcelona, November 9-16, 2016, Available at https://www.cett.es/fitxers/campushtml/ MiniWebs/122/papers/PUT_SMITH.pdf

Schieder, T.K. (2013). Mobile Applications for UNESCO World Heritage Sites: Analyzing the state-of-the-art, designing and assessing the usability of an application for two World Her- 
itage Sites in the canton of Ticino (Switzerland), Master's Dissertation, Università della Svizzera Italiana, Lugano (Switzerland), Faculties of economics and communication sciences. Available at http://www.otur.usi.ch/sites/www.otur.usi.ch/files/uploads/masterthesis_schiedertheresa.pdf

Smirnov, A., Kashevnik, A., Shilov, N., Teslya, N., \& Shabaev, A. (2014). Mobile application for guiding tourist activities: Tourist assistant - TAIS. Paper presented at Conference of Open Innovation Association, FRUCT. 2014. Oulu, Finland, October 27-31, 2014 (pp. 95-100). Piscataway, New Jersey, USA: Institute of Electrical and Electronics Engineering, IEEE https://doi.org/10.1109/FRUCT.2014.7000931

Sziva, I. (2017). Smart destinations for smart Generation? - The requirements of Generation Y in the area of innovative communication. In: 6th Conference of the IATE - International Association for Tourism Economics, 21-23 Jun 2017, Rimini, Italy. Available at http://unipub.lib.uni-corvinus.hu/2945/1/Smart_destinations_Ivett\%20Sziva.pdf

Štetić, S., \& Šimičević, D. (2014). Menadžment turističke destinacije, Belgrade, Visoka turistička škola strukovnih studija.

Štetić, S., Šimičević, D., \& Kosar, N. (2017). Uticaj informacione i komunikacione tehnologije (ICT) na potrošače u turizmu, Hotelska Kuća 2017 Conference:Inovacije u hotelijerstvu $i$ turizmu, 56-67, Zlatibor, Poslovno udruženje hotelsko ugostiteljske privrede Srbije HORES.

Štetić, S., Trišić, I., \& Nedelcu, A. (2019). Natural potentials of significance for the sustainable tourism development - the focus on the special nature reserve. Journal of the Geographical Institute "Jovan Cvijič" SASA, 69(3), 279-287. https://doi.org/10.2298/IJGI1903279S

The Travel Industry - How Mobile Apps Are Changing The Travel Habits?, DCS+ Travel Technologies, Bucharest. Available at http://www.dcsplus.net/hubfs/PDF/Resources/How-mobile-apps-are-changing-travel-habits.pdf?t=1531405451357

Tjostheim, I., \& Holmqvist, K.A. (2010). Mobile Applications and Tourist Information In Situ, in Gretzel, U., Law, R.\& Fuchs, M. (Eds) Short Paper Track, ENTER 2010 Conference on Information and Communication Technologies in Tourism. Available at http://agrilife.org/ ertr/files/2013/02/17-p78f.pdf

Trišić, I., Štetić, S., Privitera, D., \& Nedelcu, A. (2020). Wine routes in Vojvodina Province, Northern Serbia - a tool for sustainable tourism development. Sustainability, 12(1), 82. https://doi.org/10.3390/su12010082

Trišić, I., Štetić, S., \& Krstić, V. (2018). Possibilities to prevent negative environmental impacts. Economics of Agriculture, 65(4), 1599-1614. https://doi.org/10.5937/ekoPolj1804599T

Trišić, I. (2019). Opportunities for sustainable tourism development and nature conservation in Special Nature Reserve "Deliblatska Peščara". Hotel and Tourism Management, 7(1), 8393. https://doi.org/10.5937/menhottur1901083T

Van Wee, B., Chorus, C., \& Geurs, K. (2013). Information, communication, travel behavior and accessibility. Journal of Transport and Land Use, 6(3), 1-16. https://doi.org/10.5198/jtlu. v6i3.282

Yalçınkaya, P., Atay, L., \& Korkmaz, H. (2018). An Evaluation on Smart Tourism. China-USA Business Review, 17(6), 308-315. https://doi.org/10.17265/1537-1514/2018.06.004

Yus, F. (2014). Mobile Tourism: Discourse, Interactivity And Usability In Mobile Apps For Tourism, Paper delivered at Discurso y Géneros del Turismo 2.0. Valencia: University of Valencia and IULMA, April 2014. Available at https://personal.ua.es/francisco.yus/site/ mobile.pdf

Zelenka, J. (2009). Information and Communication Technologies in Tourism - Influence, Dynamics, Trends. E+M Ekonomie a Management, 2009(1), 123-132. 
https://doi.org/11025/17278

https://bevasarloutca.hu/en/about-us

https://www.budapestinfo.hu/search-results

https://www.infozagreb.hr/explore-zagreb/apps

https://play.google.com/store/apps/details?id=rs.bginfobox.belgrade.android\&hl=en

https://play.google.com/store/apps/details?id=co.infinum.zagrebbethere

https://play.google.com/store/apps/details?id=hu.bum\&hl=en

http://www.tob.rs/useful-informations/mobile-app/belgrade-info-guide 